\title{
THE TRACES INVESTIGATION OF ORAL LITERATURE AS A CULTURAL IDENTITY ON MADURA ISLAND
}

\author{
Sulaiman $^{1}$, Muhammad Busyro Karim ${ }^{2}$ \\ \{lieeman21@gmail.com ${ }^{1}$ \& busyrokarim.dz@gmail.com $\left.{ }^{2}\right\}$ \\ ${ }^{1,2}$ Universitas Trunojoyo Madura, Madura, Indonesia
}

\begin{abstract}
The existence of oral literature cannot be ignored. Although today its existence is sunk by written literature (text), it does not mean oral literature is not used anymore. Oral literature is still used by caregivers or parents as a means of storytelling to their children. Even in elementary and elementary schools, teachers still tell stories related to fairy tales, legends, and myths. This can happen because oral literature belongs to modest people, the wider community. Oral literature or folklore is a legacy from our ancestors. Many values taught by ancestors through folklore are believed to bring peace and happiness. Older people expect the next generation to be better so that they instill the values that are considered good to be used as a guideline by the next generation.
\end{abstract}

Keywords: oral literature, cultural identity, investigation, local wisdom

\section{Introduction}

Like the Javanese and the Archipelago communities, local wisdom, especially oral literature, naturally develops within the community itself. Like Madurese oral literature, Madurese oral literature basically naturally develops in the Madurese community.

The waning of oral literature along with the times and the loss of interest of children to know and read oral literature is a serious problem. Its existence has been eroded by globalization that presents all digital and instant media. Developing a love of oral literature along with the times in Madura Island is one solution to preserve and maintain its existence. The existence of Madurese oral literature which is loaded with values contained in it. The existence of oral literature as a cultural identity by itself can be maintained and not carried away by the development of the times that can cause the loss of his identity.

The threat of the loss of Madura cultural identity rooted in local wisdom is very disturbing. This can be seen from the attitudes and behavior of the younger generation, the next generation began to ignore the cultural life of local wisdom. One reason is because they forget the original character as a Madurese. [1] says this local wisdom as well as locals perspectives toward the natural sources hold prominent role to preserve their cultural heritage and identity.

Therefore, it is necessary to explore the values of local Madurese wisdom. One of the efforts that can be done is to trace the values of local wisdom that originate from oral literature on Madura Island. This effort is expected to show the image of Madurese people who are religious, polite and virtuous. 


\section{Methodology}

\section{Oral Literature, Oral Traditions, and Local Wisdom}

Understanding these three terms is important as the basis for writing this article so that the similarities and differences of the three terms are clear. In simple oral literature are things or events that occur in society, passed down from generation to generation, from one generation to the next generation orally. Oral literature prioritizes verbal communication. The events passed down from generation to generation certainly develop from local culture, customs. The process of inheritance from previous generations to the next generation continuously shows word of mouth indicating the existence of oral traditions in these societies. As for the events that are the objects of the telling are local wisdom of the local community.

Deeply, oral literature can be seen from the following expert opinions. [2]defines oral literature as literature which includes the expression of citizens' literary culture that is transmitted and passed down orally (word of mouth). In line with this opinion, [3] argues that oral literature is a literary work whose spread is conveyed by word of mouth. Meanwhile, [4]states oral literature as verbal speech that has characteristics as literary works in general, including poetry, prose, singing, and oral drama. Oral literature is a part of oral tradition or that is usually developed in oral culture in the form of messages, stories, or testimonies or passed on orally from one generation to another. Thus, it can be concluded that oral literature is a literary work or events that are delivered orally and hereditary.

Meanwhile, strengthening the understanding of oral traditions can be seen in the formulation of UNESCO [2] which expresses oral traditions as traditions transmitted in time and space with speech and action (those traditions which have been transmitted in time and space by the word and act). [4] formulating oral traditions in general is all kinds of verbal information in the form of reports about a thing that happened in the past, "Oral traditions consist of all verbal testimonies which are reported statements concerning the past.

The local wisdom is part of the culture of a society that cannot be separated from the existence of the community itself. Local wisdom is shaped and passed down from one generation to the next through word of mouth. Meanwhile, [5] local wisdom refers to a variety of cultural wealth that grows and develops in society, and is an important element to strengthen social cohesion among citizens. Based on this opinion it can be made clear that local wisdom has a high level of solidarity with its environment. Solidarity is what will strengthen and affirm the values of a noble, dignified, philosophical life that can be used as a guide for living in society.

\section{Finding and Discussion}

\section{Madurese Communities and Cultural Values}

To behave wisely is to behave in accordance with ethics and etiquette that applies in society. Behaving unwise is behavior violating ethics and etiquette. To all norms and values used by the community to find out how human should run his life [6] Many of these things are related to Madurese cultural values, which are reflected in the proverbs (expressions), syi'ir, macapat, and others. Local Madurese wisdom strongly prioritizes manners, as in the saying: "Oreng andhi' tatakrama reya akantha pesse singgapur, ekabalan ja'a e dhimma bai paju" (People who have good manners are like Singapore money (gold), spent wherever. it certainly sells). In this case Madura's local wisdom offers the concept of "andhap asor", which is an attitude of "humility" to anyone. The modesty gained from appreciation and piety to Allah SWT will make someone want to respect others properly and fairly. From this harmony and 
togetherness are fostered, so that the attitude of ere (envy), jealousy, thorns, first of all 'acethak duwa', bellu 'abunto' are ', is considered to be an embarrassing and degrading attitude of the Madurese community.

Sims and Stephens, quoted in [7] assert that folklore is a legend, myth, art, and tradition, constructing local wisdom which later became the moral-ethical teachings of the life of the local community. Deeply, the focus of this article is the folklore that developed on Madura Island. The selection of object of study is focused on folklore that is not yet known by the wider community. This is an effort to explore and develop the existence of folklore, especially those which have not been revealed much. Some examples of these folklore are: (1) Buju 'Resbejeh, (2) Tlandung Springs and (3) Toroan Waterfall.

\section{Buju 'Resbejeh}

The Buju 'Resbejeh story is a sacred tomb (asta) in Arosbaya. In Madura, Arosbaya is called Resbejeh. The name Resbejeh itself is derived from the word Keres Bejeh Pote (White Crocodile Keris). Buju 'Resbejeh was the place where Sheikh Abdul Wahid Trunokusumo was buried, an emissary from the Solo Palace. There are two versions that are similar but not the same. First, a white crocodile with a white keris (Bejeh Pote Abunto 'Kerres Pote). Second, a white crocodile on its waist is tucked in a white dagger (Bejeh Pote Nyongkel Kerres Pote). This tomb is not much people know, especially for people outside Madura. However, someone dances from this place, if someone comes and doesn't say hello there will be bad luck for that person. Usually people who make pilgrimage to the tomb then he will read the yasin, tahlil and closing praying, both praying for the soul of himself and his family to get the safety and happiness of the afterlife. However, in Buju 'Resbejeh the practice carried out was reading seven times of Al-Kahfi's.

The interesting thing is with the reading of the Al-Kahfi [8] Surah Al-Kahf consists of 110 verses, in which four stories can be found. First, the Al-Kahf is also called Ashabul Kahf (cave dwellers). Explained from verse 9 to verse 26. Tells the existence of young men of faith. Young people who realize that youth is a time of existence with reasoning (thought processes) and adequate physical strength. There are two strengths, namely spiritual and physical. As the story of Ashhaabul Kahfi, before they exiled themselves to the cave in order to preserve and defend aqidah, with two forces they voice the truth and uphold the sentence monotheism even though they have to deal with the tyrannical authorities. This teaches us the values of faith and living unyielding to uphold the truth.

Second, it is called Shaahibul Jannatain (owner of two gardens). explained from verse 32 to verse 44 . The story of the arrogance of a garden owner who does not believe in the power of Allah SWT. Do not believe in doomsday and his wealth will save his life. This story serves as an example for us that property will be a disaster for our kufr. Abundance of property can make humiliating owners in the world and the hereafter if there is no faith in us.

Third, narrating the journey of Musa (as) who sought knowledge from the US Haidir Prophet (not including the Messenger of Allah). The story is told from the 60th verse to the 82nd verse. The essence of this story is that everything on earth and everything in it belongs to Allah SWT. The knowledge we obtain is a gift from Allah SWT. In studying we must not look down on anyone. Pride will lead us to the faith. Therefore our knowledge must be based on faith.

Fourth, tells the story of Dhul Qarnain (owner of two horns). The story starts from verse 83 to verse 98. The most important thing in this fourth part is the importance of power in the hands of believers. Pengauasa who realize that the position is a mandate that will be 
accountable to Allah SWT. Power is not made into arrogance, acts arbitrarily, piling up wealth. However, the power we have must be based on faith.

\section{Tlandung Springs}

Like humans, places also have their own biodata, including Tlandung Springs. The story of the origin of the Tlandung Spring begins with a beautiful woman in the village of Asem Jaran who is pregnant for three months. The woman craved, had a desire that must be implemented that is washing her body with original water sources. Water sources originating from underground. Finally, she asked her husband to find the source. In the search, the husband met a famous kyai. Without notifying his intention, the Kyai already knew the purpose of his arrival and he was told to take a spring for your wife. It is not easy to take it, but with the belief that everything in the world is impossible to achieve if it is fought hard. Finally, he got it and rushed home to immediately give the spring to his wife.

Behind the story, there is a myth that developed in the local community. Myth, if there is someone who is dating in a river area that originates from a spring then their relationship will end after they return from Tlandung. If anyone takes anything around the river, he will get sick. Some oddities that are seen are beyond logic. However, there are good values contained in the myth. Everything that happens has become a provision of Allah SWT. Although this river is not large, it never lacks water, never recedes and never overflows.

The lesson to be learned from this myth is that life must be lived with confidence. All things that become ideals must be fought for in earnest. We believe that the provisions of Allah SWT are absolute. There is no doubt in it. In addition, stealing, taking other people's property that is not his right, being together is not because muhrim are things that are forbidden by religion. Because it must be shunned.

\section{Toroan Waterfall}

The story of the beginning of the Toroan Waterfall began with a husband and wife, Sitti Fatimah and Syayid Abdurrahman (Birenggo). Initially the husband and wife lived in harmony and happiness. However, extraordinary squabbles ensued. They accuse each other of accusation that there is betrayal between the two. Finally they took the oath which was witnessed by the public. The oath of both can be described as follows.

"That when Birenggono died, he asked his body to be buried in the limestone hill by using a branch to dig it up. If he is correct, it will be easy to dig his grave on top of a limestone hill using a tree branch. If he is guilty, the grave cannot be dug ".

"That when Siti Fatimah died, she asked for her body to be buried in the middle of a river that had a very heavy flow. If he is not mistaken, he will not be swept away by Sugai water. However, if he is guilty, his grave will be washed away by the water of Sugai."

After a few years later, a couple died simultaneously. Then the local people buried according to their wills. When the local people dug up the grave and buried Siti Fatimah downstream of Sugai, it turned out that the flow of Sugai seemed to avoid the tomb and split into two streams leading to the sea to form a waterfall. Then the local people named Toroan Waterfall. Derived from the word 'toron' (Madura), which means down (Indonesian). The evening of Fatimah by the local community was called Asta Buju, Penyeppean. The body of Birenggono was buried on the limestone hill in accordance with his will. When digging the grave, the community only planted one jatropha branch, then immediately formed a grave, then ate Birenggono buried. Local people are known as Asta Kam Tengghi because the meal is located on a high hill which is not far from the grave of his wife named Siti Fatimah. Until 
now, this couple is close to Toroan Waterfall and is still preserved and preserved by the local community.

The lesson to be learned from this legend is the importance of trust and love between husband and wife. Marital life must be based on these two things as the foundation to build a peaceful and lasting family until the end of life. Is not when deciding to live together, there is a commitment to entrust each other's dreams for the two of them. Therefore, it is very important in every relationship based on love. With love we can respect, nurture, love, care and empathize with our partners. With love we are able to change thoughts, steps, plans, ideals, principles, and strengthen what someone already has. In other words, love is something that can change a person's life in various aspects. So that compassion becomes important for survival.

\section{Conclusions}

One thing that cannot be denied is that society develops with its culture. The more sought after and explored, the more culture, especially local coffee that has not been revealed in the wider community. Such is the case with local wisdom related to folklore on Madura Island. Some examples of these folklore are: (1) Buju 'Resbejeh, (2) Tlandung Springs and (3) Toroan Waterfall

From these three folklore, we can see the noble values of local wisdom from Madura oral literature, namely: (1) courtesy in relationships between people, (2) faith and faith, (3) faith and not infallible, (4) faith and science, (5) faith and power, (6) faith and perseverance, and (7) trust and love. The seven noble values can be used as a foundation in daily life. It also increasingly shows that local wisdom through oral literature on Madura Island has a high value. Already these values should be revitalized so that they can be applied in everyday life.

\section{References}

[1] A. Liliweri, Pengantar Studi Kebudayaan. Bandung: Nusa Media, 2014.

[2] S. S. Hutomo, Mutiara yang Terlupakan: Pengantar Studi Sastra Lisan. Surabaya: Himpunan Sarjana Kesusasteraan Indonesia, 1991.

[3] S. Endaswara, Metodologi Penelitian Sastra. Yogyakarta: Pustaka Widyatama, 2003.

[4] J. Vansina, Oral Tradition. England: Penguin Book Ltd, 1973.

[5] J. Haba, Social History of the Kaili People in Central Sulawesi, An Ethnographic Approach. 2008.

[6] L. Unsriana, "Nilai Kearifan Lokal dalam Cerita Rakyat Jepang (Minwa)," J. Hum., vol. 4, no. 1, pp. 310-317, 2013.

[7] E. Herminingrum, S. \& Junining, "Socio-Cultural Life Of Kelud People In Connecting With Traditional Mitigation Effort Based On Local Wisdom,” Int. J. Soc. Local Econ. Governance, vol. 2, no. 2, pp. 127-135, 2016.

[8] T. Sahifa, Al Quran dan Terjemahan. Jakarta: Sahifa., 2017. 